\title{
ErgoVSM: A New Tool that Integrates Ergonomics and Productivity
}

\author{
Denisse Dominguez-Alfaro (D), Ismael Mendoza-Muñoz iD, Mildrend Ivett Montoya-Reyes (iD, \\ Carlos Raúl Navarro-GonzáleziD, \\ Samantha E. Cruz-Sotelo iD, Olivia Yessenia Vargas-Bernal iD \\ Universidad Autónoma de Baja California (Mexico) \\ dominguez.denisse@uabc.edu.mx, ismael.mendoza@uabc.edu.mx,mildrend.montoya@uabc.edu.mx,.cnavarro51@uabc.edu.mx, \\ samantha.cruz@uabc.edu.mx,olivia.yessenia.vargas.bernal@uabc.edu.mx
}

Received: March 2021

Accepted: May 2021

\section{Abstract:}

Purpose: Identifying possible ergonomic risks generated by the implementation of Lean Manufacturing in organizations. Shows a need to integrate ergonomics and productivity indicators in process analysis, thus giving place to the ErgoVSM methodology, which is VSM (Value Stream Mapping) complemented with ergonomic analysis.

Design/methodology/approach: This literature review aims to refer to the methodology and instruments used for its application, as well as the benefits obtained and the challenges that arise when applying it.

Findings: This article presents a review of 26 publications regarding the ErgoVSM methodology. The ErgoVSM is mainly based on the VSM methodology developed by Rother \& Shook that is most applied in the healthcare sector with ergonomic analysis instruments that focus on the physical and psychosocial factors of the workers.

Originality/value: The review revealed that when using ErgoVSM, processes can be improved from the ergonomic perspective without negatively affecting productivity. Even though ErgoVSM requires more time for application compared to VSM, the value of the ergonomic data for decision making in process changes justifies the extra time.

Keywords: ErgoVSM, VSM, value stream mapping, ergonomics, human factors

\section{To cite this article:}

Dominguez-Alfaro, D.,Mendoza-Muñoz, I, Montoya-Reyes, M.I., Navarro-González, C.R., Cruz-Sotelo, S.E., \& Vargas-Bernal, O.Y. (2021). ErgoVSM: A new tool that integrates ergonomics and productivity. Journal of Industrial Engineering and Management, 14(3), 552-569. https://doi.org/10.3926/jiem.3507

\section{Introduction}

In the last decades, manufacturing has been a constant game of doing more with less, and one of the key strategies that have changed the way Lean Manufacturing is produced is to demonstrate that it leads the companies that apply it to reach high production efficiency levels (Pampanelli, Found \& Bernardes, 2014). 
The history of Lean Manufacturing begins in Japan after World War II as a survival technique that pushed the automobile company Toyota to focus on low-cost production (Khani, Salehi \& Sajad, 2018). The publication of the book "The Machine that Changed the World" (Womack, Jones \& Ross, 1990) drove the growth of Lean Manufacturing and its acceptance as a highly beneficial practice for companies from different industries (Abu, Gholami, Mat-Saman, Zakuan \& Streimikiene, 2019). As time went by, Lean Manufacturing has demonstrated that it can adapt to the changing needs of organizations, which is why it continues to be used (Hernandez-Matias \& Vizan-Idoipe, 2013).

There are several application tools within Lean Manufacturing. VSM or Value Stream Mapping stands out among them because it is considered a key element to initiate implementation of the methodology (Madariaga-Neto, 2018). Rother \& Shook define VSM as all the actions (both value-added and non-value added) currently required to produce a product (Rother \& Shook, 2009). VSM shows the material flows in the company's processes through a graphic model that illustrates all the productive activities to identify the value chain and detect where the most waste is produced in the process (Hernandez-Matias \& Vizan-Idoipe, 2013).

Lean Manufacturing and its application tools aim to reduce or eliminate activities that do not add value (Villaseñor \& Galindo, 2007). Addressing the activities identified as waste or non-value-added improves productivity in companies (Leong, Lam, Ng, Lim, Tan \& Ponnambalam, 2019). Lean Manufacturing identifies the following activities as waste: overproduction, waiting, transportation, overprocessing, inventories, defects, and unnecessary motion (Santos, Vieira \& Balbinotti, 2015). The waste of human talent has been added recently (Wahab, Mukhtar \& Sulaiman, 2013).

The goal of Lean Manufacturing does not consider the impact of the changes in processes on the workers (Dombrowski, Reimer \& Wullbrandt, 2018). Some studies demonstrate that rigorous application of Lean Manufacturing can be associated with an increase in musculoskeletal disorders (MSD) as well as work stress (Botti, Mora \& Regattieri, 2017; Dombrowski et al., 2018; Koukoulaki, 2014). MSD increase is related to repetitive activities or critical postures for the workers that result from applying productive improvements to the processes (Botti et al., 2017). Eliminating inefficient worker motions that are considered not to add value to the product may generate ergonomic risk factors since sometimes these activities represent physical and mental recovery periods for the workers. (André, Heldal \& Edwards, 2015; Dombrowski et al., 2018; Koukoulaki, 2014).

By identifying a lack of consideration of ergonomic risks in the rigorous implementation of Lean Manufacturing, as well as the consequences, it could have for the worker (Edwards, Winkel, Laine, Sinervo, Sjovold, Bragadottir et al., 2012), the integration of Lean Manufacturing Ergonomics has been pushed in order to apply the analysis methods that allow identifying ergonomic risks at work (Dombrowski et al., 2018).

The International Ergonomics Association defines ergonomics as the scientific discipline concerned with understanding interactions among humans and other elements of a system and the profession that applies theory, principles, data, and design methods to optimize human well-being and overall system performance (Thatcher \& Yeow, 2018). Ergonomics is divided into three fields of specialization (IEA, 2019): Cognitive, which is concerned with mental processes, focusing on mental workload and work stress; organizational, whose relevant topics are the optimization of sociotechnical systems, their structures, policies, and processes; and physical, which is related to the physical characteristics of human beings and the activities they perform.

Making ergonomic improvements once the process has been designed from a productivity point of view has demonstrated that it does not solve problems at the root since the processes are not designed in full but only focusing on specific activities (Edwards, 2014). The concept of VSM with ergonomic analysis (ErgoVSM) arises as part of an effort to highlight the importance of including Ergonomics in Lean Manufacturing (Jarebrant, Birgisdóttir, Dudas, Edwards, Gunnarsdóttir, Harlin et al., 2014). ErgoVSM seeks to raise awareness of ergonomics among the people who design the processes, who rarely understand the ergonomic impact on workers, and encourages the integral use of Ergonomics and productivity when planning production (Mathiassen, Jarebrant, Birgitta \& Winkel, 2004). 
The purpose of this work is to analyze the recent literature on the application of ErgoVSM technology using a descriptive review to demonstrate its notable benefits, the challenges that come up in its application, and the main tools used for ergonomic analysis, and the methodology used for its implementation.

\section{Method}

\subsection{Search Process and Inclusion and Exclusion Criterion.}

A literature review was conducted between May and June of 2020 to identify the works related to the concept or application of the VSM methodology, including ergonomic analysis. The keywords defined for this research are: Ergonomics, Ergonomic, VSM, and Value Stream Mapping. The word Green, which refers to reducing negative environmental impacts and ecologic efficiency improvement, was used as an exclusion criterion. (Zhan, Tan, Ji, Chung \& Chiu, 2018). In the last years, the Lean-Green union has become more relevant worldwide because it seeks both operational and environmental efficiency in the processes (Abreu, Alves \& Moreira, 2017). The union of Lean Manufacturing tools and the environmental approach is not within our study area; thus, it was defined as an exclusion criterion.

Search keywords and the exclusion criterion are combined using the Boolean operators "OR", "AND", "NOT", as well as the use of parentheses to define the search. They were combined as follows: ("Ergonomic" OR "Ergonomics") AND ("VSM" OR "Value Stream Mapping") NOT ("Green"). The language was another exclusion criterion; only articles written in English and Spanish were considered.

In the first stage, the search was conducted using the databases Science Direct, Springer, and Google Scholar (see Figure 1). The title and abstract of each publication were checked as a first filter, and then the full text was analyzed to select the publications to be included. As the last step to complete the search, it was decided to review the references included in the chosen articles to have a full review of the publications.

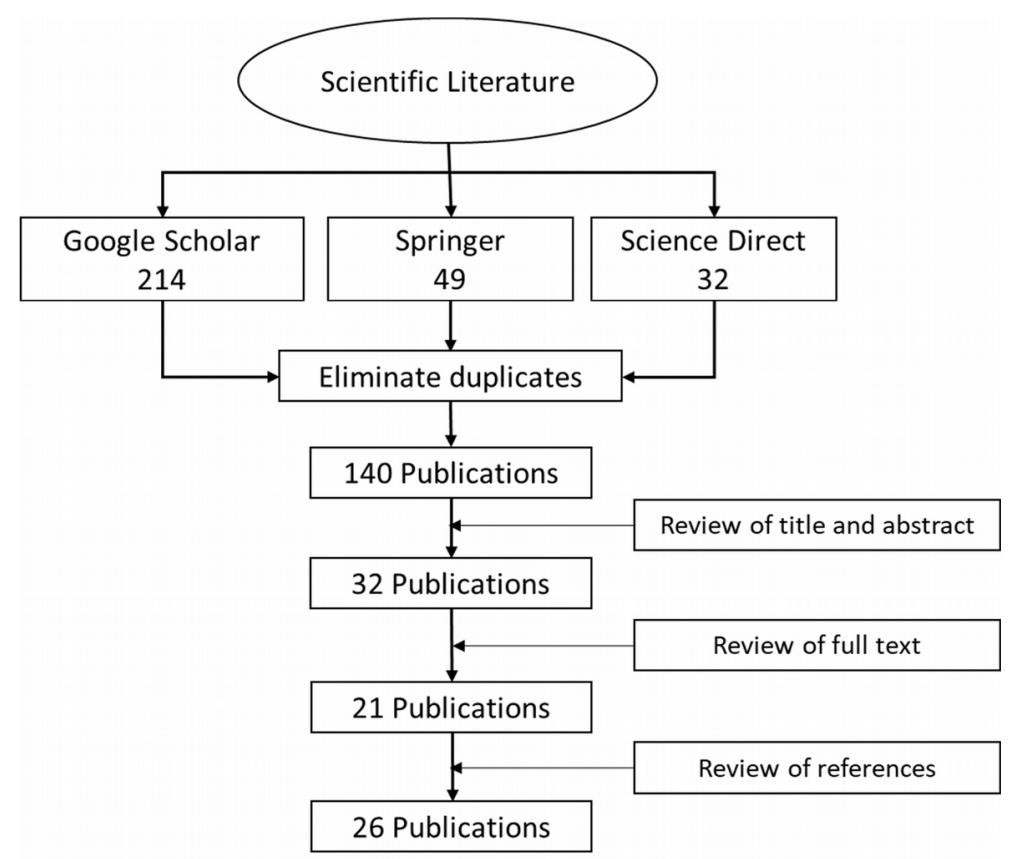

Figure 1. Flow chart of the research method

\subsection{Descriptive Information}

Twenty-six products related to ErgoVSM were selected (See Table 1). Eighteen of these products are case studies in which the methodology is applied mainly in the healthcare sector. In contrast, the rest of the studies approach ErgoVSM at a conceptual level, describing the methodology, suggesting its application, or describing the advantages of uniting Ergonomics with the production approach. 


\section{Development and discussion}

\subsection{Concept and Goal of ErgoVSM}

In the literature, the concept of ErgoVSM has not varied significantly since it was defined for the first time in by Mathiassen et al. (2004) as a complement of VSM methodology to highlight ergonomic indicators in production systems. ErgoVSM originates after identifying that both VSM and Lean Manufacturing lack ergonomic considerations in their analyses and only consider indicators that are focused on productivity. This deficiency can result in the intensification of work, which increases the ergonomic risks that lead to worker disability leaves (Edwards, Dudas, Hanse, Harlin, Hegstad, Holte et al., 2009).

\begin{tabular}{|c|c|c|}
\hline Article & Type of Publication & Application \\
\hline Mathiassen et al. (2004) & Conference Proceeding & Conceptual \\
\hline Neumann and Winkel (2005) & Journal Article & Conceptual \\
\hline Jarebrant, Dudas, Harlin, Hanse and Winkel (2009) & Conference Proceeding & Conceptual \\
\hline Edwards et al. (2009) & Conference Proceeding & Conceptual \\
\hline Jarebrant, Dudas, Harlin, Hanse and Winkel (2010) & Conference Proceeding & Conceptual \\
\hline $\begin{array}{l}\text { Winkel, Birgisdóttir, Dudas, Edwards, Gunnarsdóttir, } \\
\text { Harlin et al. (2012) }\end{array}$ & Conference Proceeding & Conceptual \\
\hline Edwards and Winkel (2013) & Conference Proceeding & Hospital \\
\hline Gunnarsdóttir and Birgisdóttir (2013) & Conference Proceeding & Hospital \\
\hline Winkel, Dudas, Harlin, Jarebrant and Hanse (2013) & Conference Proceeding & Hospital \\
\hline Aqlan, Lam, Testani and Ramakrishnan (2013) & Conference Proceeding & Electronics Industry \\
\hline Edwards (2014) & Conference Proceeding & Hospital \\
\hline Jarebrant et al. (2014) & Conference Proceeding & Hospital \\
\hline Winkel, Edwards, Birgisdóttir and Gunnarsdóttir (2015) & Journal Article & Conceptual \\
\hline $\begin{array}{l}\text { Winkel, Edwards, Birgisdóttir, Jarebrant, Hanse, } \\
\text { Gunnarsdóttir et al. (2015) }\end{array}$ & Conference Proceeding & Hospital \\
\hline Edwards and Winkel (2016a) & Conference Proceeding & Hospital \\
\hline Jarebrant, Hanse, Harlin, Ulin, Winkel, Edwards et al.(2016) & Book & Conceptual \\
\hline Hasle, Starheim, Jensen and Diekmann (2016) & Conference Proceeding & Hospital \\
\hline Edwards and Winkel (2016b) & Conference Proceeding & Hospital \\
\hline Jarebrant, Winkel, Hanse, Mathiassen and Birgitta (2016) & Journal Article & Automotive Industry \\
\hline Edwards (2017) & Conference Proceeding & Conceptual \\
\hline Suryoputro, Sari, Burhanudin \& Sugarindra (2017) & Conference Proceeding & Musical Instrument Industry \\
\hline $\operatorname{Kim}(2017)$ & Journal Article & Conceptual \\
\hline Arce, Romero-Dessens and Leon-Duarte (2018) & Conference Proceeding & Electronics Industry \\
\hline Pereiro da Silva and Goncalves-Amaral (2019) & Conference Proceeding & Hospital \\
\hline $\begin{array}{l}\text { López-Acosta, García-Vilches, Velarde-Cantú and Chacara- } \\
\text { Montes (2019) }\end{array}$ & Journal Article & Food Industry \\
\hline Sakthi, Jeyapaul, Vimal and Mathiyazhagan (2019) & Journal Article & Textile Industry \\
\hline
\end{tabular}

Table 1. List of articles that applied ErgoVSM, as well as their conceptual description 
Ergo VSM focuses on the VSM participatory tool (Winkel, Edwards, Birgisdóttir, \& Gunnarsdóttir, 2015) by encouraging the inclusion of people from all work groups and seeking the active cooperation of the staff to identify areas of opportunity and improvement ideas that should be deployed around the organization (Jarebrant, Hanse et al., 2016).

Regarding the terms utilized to refer to this tool, ErgoVSM predominates in 19 of these products, as the concept introduced by Mathiassen et al. (2004). The concept ERGONOVA is used by Jarebrant et al. (2009) and Edwards et al. (2009), and in subsequent studies, it is standardized with the name ErgoVSM. The rest of the works utilize very similar concepts, such as Ergonomic Value Stream Map (Aqlan et al., 2013), VSM with ergonomic evaluation (López-Acosta et al., 2019), and the singular name P-lean, named as such because it uses lean tools (VSM) that focus on improving the psychosocial factors of the work environment (Hasle, Starheim, Jensen, Diekmann \& Jensen, 2016).

The goal of ErgoVSM is to complement the analysis carried out with VSM by adding evaluations of the ergonomic consequences that arise in workers due to the current production flow (Mathiassen et al., 2004). This integration of Lean Manufacturing and Ergonomics seeks to develop sustainable flows in the process (Edwards \& Winkel, 2016b). ErgoVSM allows focusing on achieving greater efficiency, improving the work environment, and reach a sustainable work-life (Neumann \& Winkel, 2005). The methodology contributes to evaluating and drawing attention to the ergonomic risks that can happen when processes are improved (Jarebrant, Winkel et al., 2016), as well as to facilitate the participation of the workers in the evaluation of the current and future state of the process (Jarebrant et al., 2009).

\subsection{ErgoVSM Methodology}

The Rother \& Shook methodology (see Figure 2) is the most used for applying VSM in organizations (Faulkner \& Badurdeen, 2014). Therefore Jarebrant, Hansen et al. (2016), Jarebrant, Winkel et al. (2016), Suryoputro et al. (2017) and López-Acosta et al. (2019) work based on these four main steps to apply ErgoVSM: preparation; map current state; define future state; and design and execute the action plan. Below is a description of each of these stages.

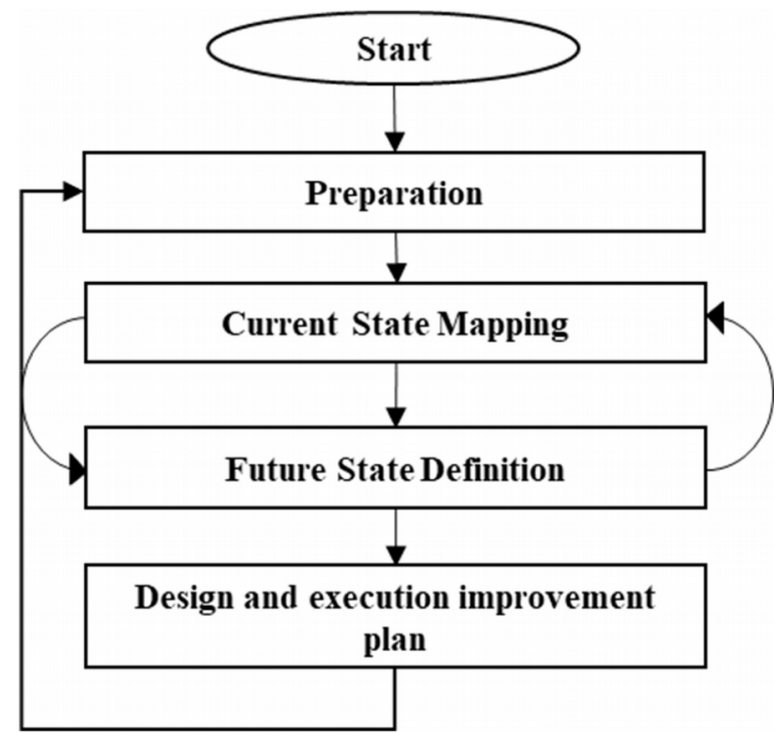

Figure 2. Workflow of the ErgoVSM Methodology Stages

Preparation: It is the essential part of the process because it ensures a successful outcome. It is where the focus of the project is determined (Suryoputro et al., 2017). This stage requires the commitment of the organization at all levels to carry out the project and select the flow to be mapped, as well as integrate the multidisciplinary work team (Jarebrant, Hanse et al., 2016). 
Current state mapping: This stage is where operations are analyzed using VSM to know the current situation of the processes, including the ergonomic tools selected (López-Acosta et al., 2019). The estimated time that activities take must be identified, the ergonomic evaluation must be carried out, data must be gathered, areas of opportunity must be identified, and improvement ideas must be developed (Jarebrant, Winkel et al., 2016).

Future state definition: Based on the issues identified in the current state, solutions that integrate Ergonomics must be created in the future state. In case this does not happen, improvement ideas must continue (Jarebrant, Hanse et al., 2016). It is vital to integrate the ergonomic improvement ideas in future VSM, as well as consider the economic risks that can arise due to changes (López-Acosta et al., 2019). Rother \& Shook emphasize that, once the current state begins to be mapped, future state ideas will emerge; this is why the arrows go both ways (see Figure 1). Sometimes the distinction between one step and the other will become so blurred that they may begin to happen simultaneously (Rother \& Shook, 2009).

Design and execution of improvement plan: It is necessary to establish an implementation schedule for each action (Jarebrant, Winkel et al., 2016), to achieve the desired future state. When making changes to the process, activities in the workstations must be evaluated to verify the changes and how they affect workers (López-Acosta et al., 2019).

Lean Manufacturing and its application tools continuously look for new ways to carry out tasks in more agile, flexible, and economical ways (Hernandez-Matias \& Vizan-Idoipe, 2013). In VSM, to achieve this desired continuous improvement, it is important that when the future state becomes a reality (current state), the future state stream map is drawn again in order to start the value chain improvements anew (Rother \& Shook, 2009).

Sakthi et al. (2019) propose the following implementation stages: a) Preparation, b) Current state mapping, c) Definition of the improvement plan, d) Execution of final plan, e) Evaluation of the results obtained after implementation of the improvement plan, f) Identification of learnings and g) Continue with the continuous improvement cycle.

Both present methodologies similarities in the first two steps, coinciding in the importance of preparing the project and selecting key indicators and team members. After building the current state, Rother and Shook (2009) indicate that an analysis of the information gathered must be carried out to define the desired future state before making changes to the processes, while Sakthi et al. (2019) opted for defining the improvement plan after building the current state of the process based on the data obtained and the areas of opportunity identified while mapping the current state.

This change by Sakthi et al. (2019) that consists of not defining the future state stands out against the importance that Rother \& Shook (2009) give to defining the desired future state by considering it the guideline that helps define improvement actions that will help us get closer to what the value flow should be. Jarebrant, Hanse et al. (2016) emphasize the importance of evaluating the future state before implementing the changes to know if the desired indicator improvements will be achieved and present the future state mapping to all the workers to help generate more improvement ideas and ensure the staff's participation in the action plan.

\subsection{Distribution by Country, Year, and Type}

The countries that make up the Nordic council stand out notably for their contributions with 19 products between Denmark, Iceland, and Sweden (see Figure 3). Additional to the countries mentioned above, this council is made up of Finland, Norway, the Faroe Islands, Greenland, and Aland, and their goal is to make this region the most sustainable and integrated of the planet (The Nordic Council and the Nordic Council of Ministers, 2018). ErgoVSM is identified as a recently discovered tool outside of the Nordic council, and it started to be used in 2013 in countries such as Brazil (Pereiro da Silva \& Goncalves-Amaral, 2019), United States (Aqlan et al., 2013), United Arab Emirates (Kim, 2017), Indonesia (Suryoputro et al., 2017), India (Sakthi et al., 2019) and Mexico (Arce et al., 2018; López-Acosta et al., 2019).

Even though Ergonomics has worked along with other sciences such as engineering or medicine since 1970 (Obregón-Sánchez, 2016), and the VSM methodology became popular in 1998 in the western countries (MadariagaNeto, 2018), most of the publications about ErgoVSM are more recent, from 2010 to 2019 (see Figure 4), so the 
methodology can be considered new. The works conducted in this area have been mainly presented at conferences, less often published in research journals, and there is only one book on the ErgoVSM methodology (Figure 4).

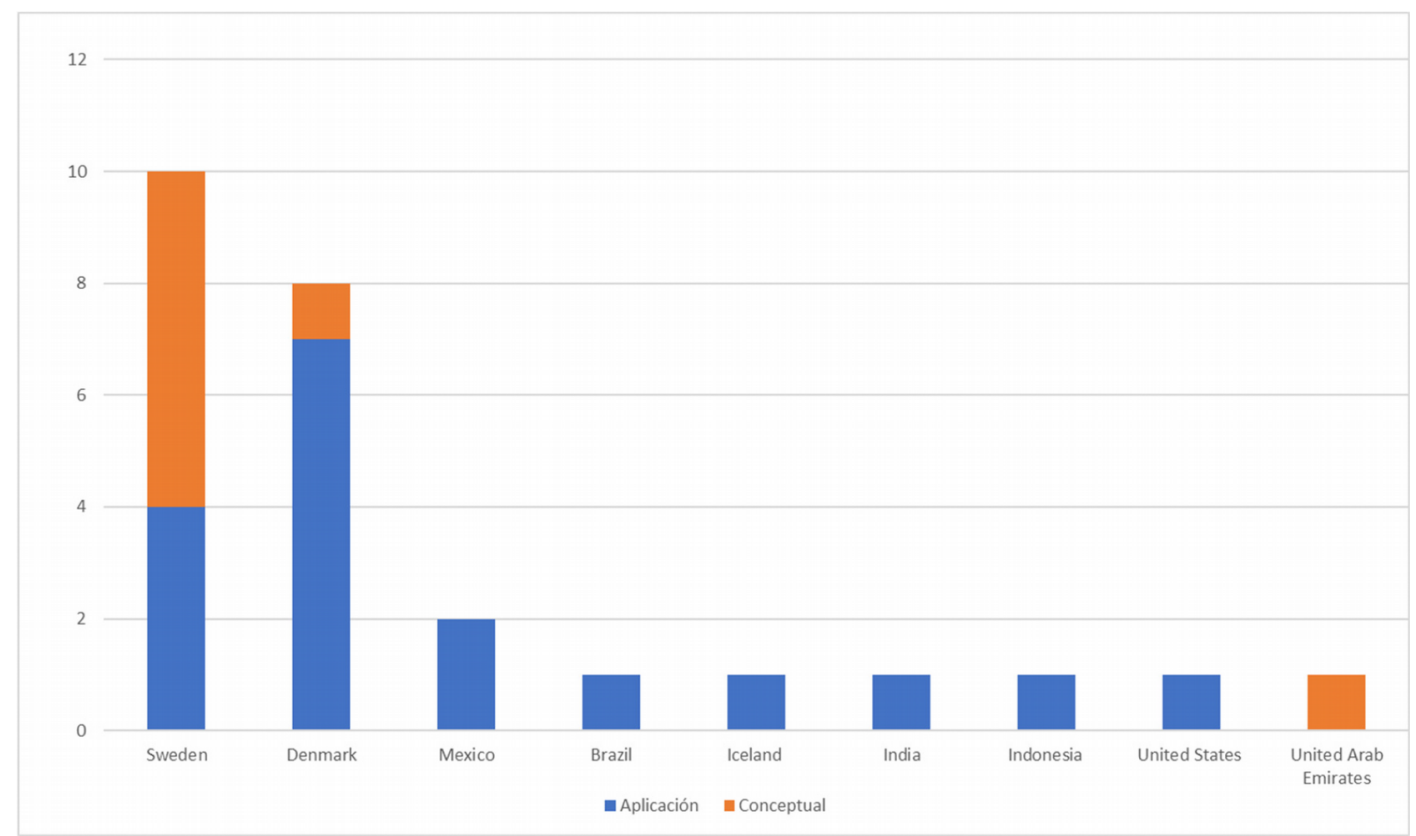

Figure 3. Distribution of products by country

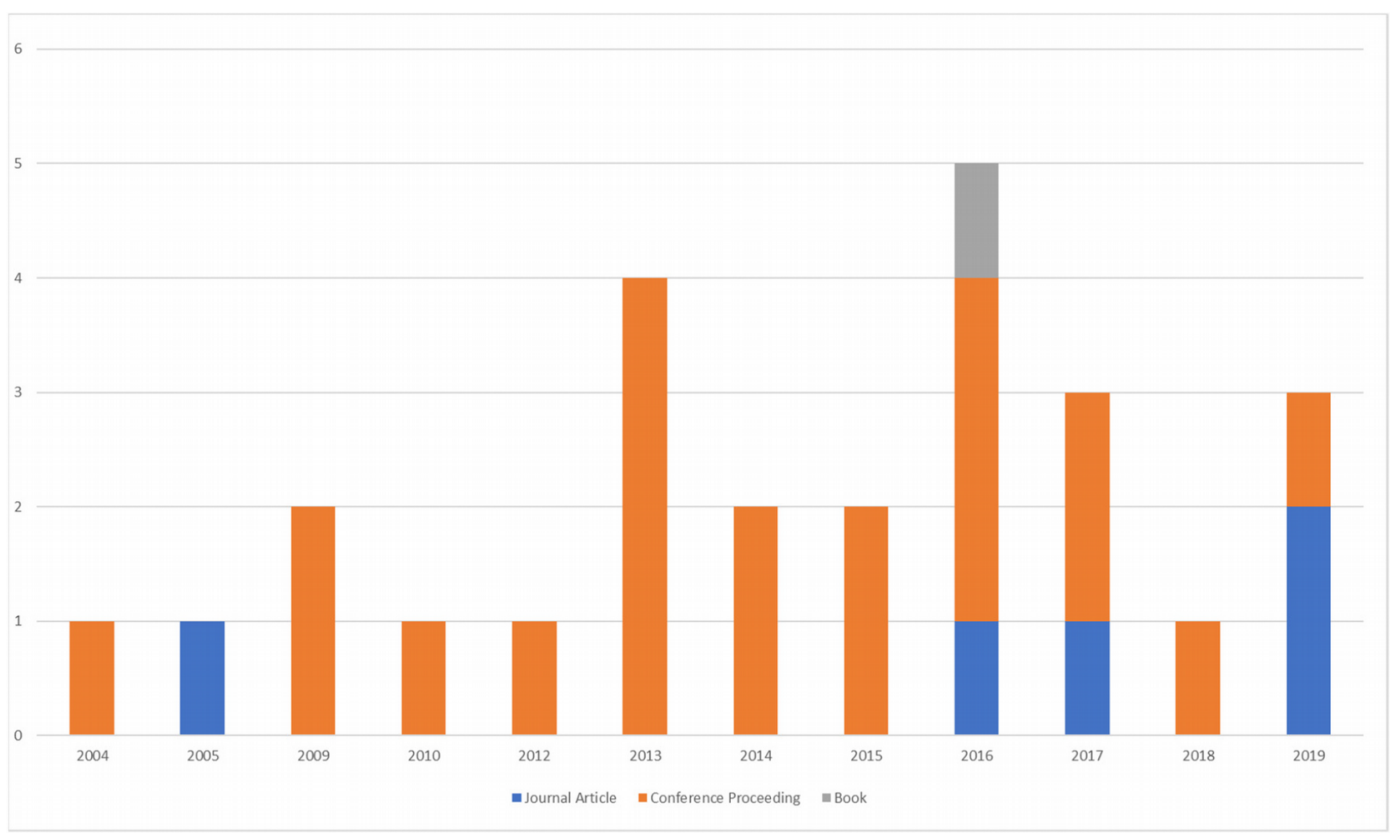

Figure 4. Distribution of products by year and type of publication

\subsection{Ergonomic Instruments Applied}

The instruments used for the ergonomic risk analysis module can be divided into those developed by the researchers themselves for the study and those that used instruments that are recognized and validated by the industry (See Table 2). The physical and psychosocial risk analysis set is the one with the most products compared to the separate studies of physical, psychosocial, or cognitive risks. 
Physical risk factors are those related to repetitive tasks, load weight, and posture (Otto \& Battaïa, 2017). Psychosocial factors refer to the work conditions relating to work organization and work environment (Fernandes, Figueiredo, Ribeiro, Neves \& Vicente, 2020). Cognitive risk factors focus on the mental load of the work, mainly stress (Kim, 2016).

Risk factors, both physical and psychosocial, have become an object of study for the application of ErgoVSM within the Nordic council due to physical and mental burnout issues detected in healthcare workers (Edwards et al., 2009). These studies (Edwards, 2014; Edwards \& Winkel, 2013; Jarebrant, Winkel et al., 2016; Winkel, Edwards, Birgisdóttir, Jarebrant et al., 2015) were led mainly by ergonomists who worked on the analysis instrument applied for more than ten years at different hospitals to improve it according to their observations. Said instrument was presented in the 2016 book Ergonomic Value Stream Mapping (Ergo VSM), Tool and User Guide (Jarebrant, Hanse et al., 2016).

The analysis of ergonomic factors in the industrial sector mainly used already known instruments that focus on identifying risk loads or postures for workers (Aqlan et al., 2013; López-Acosta et al., 2019; Suryoputro et al., 2017). Aqlan et al. (2013) stand out to develop a comfort survey for workers that touches on posture, load, noise, temperature, vibration, and lighting. Arce et al. (2018) focused on analyzing mental workload factors in the industry, and Hasle, Starheim, Jensen and Diekmann (2016) identified communication problems in the organization that reflected psychosocial factors.

\begin{tabular}{|l|l|l|l|l|}
\hline \multicolumn{1}{|c|}{ Instrument used } & \multicolumn{1}{|c|}{ Physical } & Psychosocial & \multicolumn{1}{c|}{ Cognitive } & \multicolumn{1}{c|}{ Physical and Psychosocial } \\
\hline $\begin{array}{l}\text { Previously } \\
\text { validated }\end{array}$ & $\begin{array}{l}\text { López-Acosta et al. } \\
\text { (2019) } \\
\text { Aqlan et al. (2013) } \\
\text { Suryoputro et al. (2017) }\end{array}$ & None & Arce et al. (2018) & $\begin{array}{l}\text { Pereiro da Silva and } \\
\text { Goncalves-Amaral (2019) }\end{array}$ \\
\hline $\begin{array}{l}\text { Developed by the } \\
\text { authors }\end{array}$ & Aqlan et al. (2013) & $\begin{array}{l}\text { Starheim, } \\
\text { Jensen and } \\
\text { Diekmann } \\
\text { (2016) }\end{array}$ & None & $\begin{array}{l}\text { Edwards and Winkel (2013) } \\
\text { Gunnarsdóttir and Birgisdóttir (2013) } \\
\text { Winkel et al. (2013) } \\
\text { Edwards (2014) }\end{array}$ \\
Jarebrant et al. (2014) \\
Winkel, Edwards, Birgisdóttir, \\
Jarebrant et al. (2015) \\
Edwards and Winkel (2016a) \\
Jarebrant, Winkel et al. (2016) \\
Edwards and Winkel (2016b) \\
Edwards (2017) \\
Sakthi et al. (2019)
\end{tabular}

Table 2. Types of instruments applied, and ergonomic factors analyzed in ErgoVSM

\subsubsection{Application in Hospitals}

ErgoVSM application studies have been carried out mainly in the healthcare sector, focusing on hospitals. The applications were in Nordic countries, except for the Pereiro de Silva \& Goncalves-Amaral (2019) research carried out in Brazil. They implemented the method indicated in the book "Ergonomic Value Stream Mapping (Ergo VSM), Tool and User Guide" (Jarebrant, Hanse et al., 2016) and reached the identification of areas of opportunity phase (Pereiro da Silva \& Goncalves-Amaral, 2019).

The application of Lean Manufacturing tools in the healthcare sector, known as Lean Healthcare, begun in 2001 by helping to eliminate unnecessary processes or duplicates that extended patient stays (Radnor, Holweg \& Waring, 2012). Lean Healthcare demonstrated to have positive impacts when focusing on the services that patients receive (Spagnol, Min \& Newbold, 2013).

The application of Lean Healthcare in the Nordic healthcare system gained strength after creating the NOVO Network in 2006 (Winkel, 2009). The goal of the NOVO Network is to create sustainable healthcare systems (NOVO, 2020). By identifying the possible ergonomic physical and psychosocial risks to which healthcare workers 
are exposed, they proposed implementing an ErgoVSM (Jarebrant et al., 2009; Winkel, Edwards, Birgisdóttir, Jarebrant et al., 2015).

The first applications of ErgoVSM in Nordic hospitals happened in 2013 (Edwards \& Winkel, 2013; Gunnarsdóttir \& Birgisdóttir, 2013; Winkel et al., 2013). The study aims to compare the results obtained between VSM and ErgoVSM (see Table 3). Two independent teams participated in the studies, one for VSM and the other for ErgoVSM. A more significant number of improvement ideas, as well as a lower negative ergonomic impact was identified in the ErgoVSM room proposals.

Winkel, Edwards, Birgisdóttir, Jarebrant et al. (2015) conducted a study with a greater number of hospital rooms to compare ErgoVSM against VSM (see Table 3), following the same principle of the previous studies, $50 \%$ of the rooms applied VSM, and the rest applied ErgoVSM. One result that stands out is that the rooms with ErgoVSM work teams participated on average $8 \%$ more than the VSM teams. It was also found that ErgoVSM room participation offered a $96 \%$ positive ergonomic impact on the worker compared to $84 \%$ in VSM rooms.

\begin{tabular}{|c|c|c|c|c|}
\hline Article & Country & Application & VSM Result & ErgoVSM Result \\
\hline $\begin{array}{l}\text { Edwards and } \\
\text { Winkel (2013) }\end{array}$ & Denmark & 2 hospital wards & $\begin{array}{l}\text { - } 18 \text { improvement ideas. } \\
\text { - No ideas with negative } \\
\text { ergonomic impact were } \\
\text { identified. }\end{array}$ & $\begin{array}{l}\text { - } 25 \text { improvement ideas. } \\
1 \text { idea with possible negative } \\
\text { ergonomic impact was } \\
\text { identified. }\end{array}$ \\
\hline $\begin{array}{l}\text { Gunnarsdóttir } \\
\text { and } \\
\text { Birgisdóttir } \\
\text { (2013) }\end{array}$ & Iceland & 2 hospital wards & \multicolumn{2}{|c|}{ - Pending to define future state and action plan. } \\
\hline $\begin{array}{l}\text { Winkel et al. } \\
\text { (2013) }\end{array}$ & Sweden & 2 hospital wards & $\begin{array}{l}\text { - } 22 \text { improvement ideas. } \\
\text { - } 5 \text { of the ideas were } \\
\text { considered to possibly have } \\
\text { negative ergonomic impact. }\end{array}$ & $\begin{array}{l}\text { - } 37 \text { improvement ideas } \\
\text { - No ideas with negative } \\
\text { ergonomic impact were } \\
\text { identified. }\end{array}$ \\
\hline $\begin{array}{l}\text { Winkel, } \\
\text { Edwards, } \\
\text { Birgisdóttir, } \\
\text { Jarebrant et al. } \\
\text { (2015) }\end{array}$ & $\begin{array}{l}\text { Denmark, } \\
\text { Iceland, and } \\
\text { Sweden }\end{array}$ & $\begin{array}{l}14 \text { hospital } \\
\text { wards: Denmark } \\
\text { (6), Iceland (2), } \\
\text { and Sweden (6). }\end{array}$ & $\begin{array}{l}\text { - } 84 \% \text { positive ergonomic } \\
\text { impact or without affecting. } \\
\text { - } 95 \% \text { of proposals increased } \\
\text { efficiency. } \\
\text { - } 2 \text { rooms did not complete the } \\
\text { study. }\end{array}$ & $\begin{array}{l}\text { - } 96 \% \text { positive ergonomic impact } \\
\text { or without affecting. } \\
\text { - } 88 \% \text { of the ideas would } \\
\text { improve efficiency in the rooms. } \\
\text { - } 8 \% \text { more participation in } \\
\text { improvement ideas. }\end{array}$ \\
\hline
\end{tabular}

Table 3. Comparative of VSM against ErgoVSM in hospital ward

\subsubsection{Application in the Industrial Sector}

The application of ErgoVSM in the industrial sector consists of six analyzed products. The industries included with one case each are: textiles, food, automotive, manufacturing of musical instruments. The electronics industry has two case studies, this is the highest application recurrence.

The ergonomic module in the industrial sector has focused on identifying physical risk factors related to worker posture and load (See Table 4), mainly using recognized tools that have been previously applied in the industrial sector (Aqlan et al., 2013; López-Acosta et al., 2019; Suryoputro et al., 2017). The psychosocial and physical factors of the workers were analyzed to a lesser degree (Jarebrant, Winkel et al., 2016; Sakthi et al., 2019), and only one of the products evaluated the cognitive factors related to mental load (Arce et al., 2018).

One of the most-used methods in the ergonomic risk analysis literature is REBA (Boulila, Ayadi \& Mrabet, 2018), which focuses on evaluating the position of the body of the person carrying out the task (Enez \& Nalbantoğlu, 2019). Suryoputro et al. (2017) applied the method and included the scores obtained in each ErgoVSM process. López-Acosta et al. (2019) used REBA and complemented it with physical analysis methods such as Brief, NIOSH, and MAC. 
The use of information technology programs for ergonomic risk analysis is present in the studies by López-Acosta et al. (2019) with the Ergo/IBV software, which allows evaluating repetitive movement risks, while Aqlan et al. (2013) used the Jack software to model the ergonomic risks proposed for the processes.

\begin{tabular}{|c|c|c|c|}
\hline Author & Industry & Ergonomic Analysis & Method used \\
\hline Suryoputro et al. (2017) & $\begin{array}{l}\text { Musical } \\
\text { Instruments }\end{array}$ & Physical & $\begin{array}{l}\text { - Job Safety Analysis } \\
\text { - } 10 \text { Beats } \\
\text { - REBA }\end{array}$ \\
\hline Aqlan et al. (2013) & Electronics & Physical & $\begin{array}{l}\text { - OWAS } \\
\text { - Jack Software } \\
\text { - Developed by the authors }\end{array}$ \\
\hline López-Acosta et al. (2019) & Food & Physical & $\begin{array}{ll}\text { - } & \text { Brief Method } \\
\text { - } & \text { REBA } \\
\text { - } & \text { NIOSH Method } \\
\text { - } & \text { MAC Method } \\
\text { - } & \text { ERGO/IBV Software }\end{array}$ \\
\hline Arce et al. (2018) & Electronics & Cognitive & - NASA-TLX \\
\hline Jarebrant, Winkel et al. (2016) & Automotive & Physical and Psychosocial & - Developed by the authors \\
\hline Sakthi et al. (2019) & Textile & Physical and Psychosocial & - Developed by the authors \\
\hline
\end{tabular}

Table 4. Articles that include ergonomic analyses and the methods used

A study that provides a precedent of ErgoVSM and the application of Lean Manufacturing tools with an ergonomic approach is the one carried out by Aqlan et al. (2013). However, even though the application of an ergonomic value stream map is mentioned, the information shown does not entirely coincide with the characteristics of VSM. The mapping shown is more similar to the characteristics of a flow chart. It is important to remember that the goal of VSM is to show all the actions that are carried out to produce a product, not only the individual processes (Rother \& Shook, 2009), while the flow chart helps us represent the order of operations in a given process (Cuatrecasas, 2010).

The methodology applied mainly in the Nordic healthcare sector was adapted to the automotive sector by Jarebrant, Winkel et al. (2016), comparing the results after forming three independent work teams, one of them applying the VSM methodology and two of them und ergoVSM. The results obtained show that both VSM and ErgoVSM can achieve similar production performance results, but only ErgoVSM teams included improvements regarding work conditions (Jarebrant, Winkel et al., 2016).

Sakthi et al. (2019) developed a physical and psychosocial analysis instrument and applied it in the textile sector in collaboration with Lean Manufacturing and Ergonomics experts. The instrument was validated by applying it to a sample and carrying out a reliability test. Sakthi et al. identify a lack of indicators focused on the security and hygiene of the workers who also contribute to the performance of activities as a limitation of the instrument.

\subsection{Lean Manufacturing Tools Used}

Lean manufacturing has different tools to achieve continuous improvement, which can be applied independently or together, depending on the needs detected in the organization of the study (Hernandez-Matias \& Vizan-Idoipe, 2013). The application of ErgoVSM in the industrial sector has been implemented in $80 \%$ of the cases using Lean Manufacturing tools (see Table 5), while the healthcare sector does not indicate the use of more continuous improvement tools. 


\begin{tabular}{|c|c|c|}
\hline Author & Industry & Lean Tool \\
\hline Aqlan et al. (2013) & Electronics & $\begin{array}{l}\text { - SIPOC (Analysis) } \\
\text { - Cause and effect diagram (Analysis) }\end{array}$ \\
\hline López-Acosta et al. (2019) & Food & $\begin{array}{l}\text { - Kanban (Application) } \\
\text { - Kaizen (Application) } \\
\text { - Poka-yoke (Application) } \\
\text { - SIPOC (Analysis) }\end{array}$ \\
\hline Arce et al. (2018) & Electronics & $\begin{array}{l}\text { - Kaizen (Application) } \\
\text { - Gemba Walk (Analysis) } \\
\text { - } 3 \mathrm{P} \text { (Application) }\end{array}$ \\
\hline Sakthi et al. (2019) & Textile & - Gemba Walk (Analysis) \\
\hline Suryoputro et al. (2017) & Musical Instruments & - Considers ergonomic risk factors as the ninth waste. \\
\hline
\end{tabular}

Table 5. Lean Manufacturing tools used in ErgoVSM

The tools that were used the most were the SIPOC diagram (Aqlan et al., 2013; López-Acosta et al., 2019), and Gemba Walk (Arce et al., 2018; Sakthi et al., 2019), which were used to complement ErgoVSM in the current state mapping stage, which helps to know the processes and identify production problems. Kaizen was mainly used in the step corresponding to designing and executing the improvement plan (Arce et al., 2018; López-Acosta et al., 2019).

The SIPOC tool is a process diagram that identifies suppliers, inputs, process, outputs, and customers (Gutiérrez \& de la Vara, 2013). The application of SIPOC allowed López-Acosta et al. (2019) and Aqlan et al. (2013) to know the manufacturing process and identify and analyze the ergonomic risks of the activities performed.

Gemba Walk refers to seeing the actual process or the production area in this case (Flumerfelt \& Wenson, 2019). Sakthi et al. (2019) used it as the first step to collect data, observe the process, and interview the production workers. Arce et al. (2018) applied Gemba Walk to identify areas for improvement in the processes. These applications highlight the importance that Imai (2012) gives to being present in the workplace and then apply continuous improvement.

The most used tool to design and execute the improvement plan is Kaizen, a Japanese word that has been generally translated as a continuous improvement (Imai, 2001). The application by López-Acosta et al. (2019) and Arce et al. (2018) focused on creating Kaizen team works to solve areas of opportunity in the process. Previous applications of Lean Manufacturing tools in ErgoVSM demonstrate the adaptation of this production system to achieve better situations that focus either on productivity or ergonomic risks.

An approach that goes beyond complementing Lean Manufacturing tools with Ergonomics is that of Suryoputro et al. (2017) considers ergonomic risks as another type of waste within lean manufacturing, so these risk factors must be reduced or eliminated just like all traditional waste in the methodology. Including a new waste approach is a topic also developed by Dombrowski et al. (2018) and Dombrowski, Reimer and Stefanak (2019), by considering that avoiding waste from the customer point of view is not enough, that worker health must be included in the goals, and that due to musculoskeletal disorder increase, an inclusive and sustainable work design is required.

\subsection{Benefits of ErgoVSM application}

Among the benefits of applying ErgoVSM that were identified, one that stands out is the union it achieves between improvement activities by considering the ergonomic conditions of the workers and the key productivity indicators, thus obtaining ergonomic improvements that do not affect operational performance and successfully encourage process improvement (Jarebrant, Winkel et al., 2016). The adaptation of ErgoVSM has demonstrated that it reduces the negative effects that the application of Lean Manufacturing can have on the quality of life of the workers (Sakthi et al., 2019). 
Analyzing the ergonomic risks before implementing an improvement plan avoids the intensification of activities and encourages discussion and the contribution of ideas by the staff (Jarebrant, Hanse et al., 2016). The union of Ergonomics and VSM offers the possibility of improving communication and coordination issues, thus ensuring the participation of the workers in implementation (Hasle, Starheim, Jensen, \& Diekmann, 2016). Applying the ErgoVSM methodology facilitates the analysis of ergonomic issues in the processes (Edwards \& Winkel, 2016b) and identifies the intensification of work after an improvement (Westgaard \& Winkel, 2011).

Using ErgoVSM helps us achieve sustainable systems (Jarebrant et al., 2010; Jarebrant, Winkel et al., 2016). In the Nordic health sector, sustainability has been defined as achieving efficiency in patient care, improving the work environment in healthcare organizations, and complying with patient care quality standards (Sinervo, Laine \& Pekkarinen, 2013).

\subsection{Challenges}

Most of the challenges found for the implementation of ErgoVSM in an organization stem from the application of traditional VSM. This is evident because ErgoVSM is a tool that complements VSM. It should be emphasized that there must be a commitment and responsibility of the management, as well as constant effort and a strong conviction to be able to adapt the methodology to the selected process (Rother \& Shook, 2009).

Lack of communication and coordination in the tasks to be completed by different groups or departments result in the work team losing the focus to solve problems or considering that the situation cannot be changed (Hasle, Starheim, Jensen, \& Diekmann, 2016). Implementing a multidisciplinary team is recommended to allow achieving an analysis based on the knowledge of the activities carried out by all the teams (Jarebrant, Hanse et al., 2016). On the other hand, work teams must have responsibility, participation, and focused leadership in order to be able to achieve the appropriate changes; if this is not present, the possibilities of successfully implementing the tool decrease (Jarebrant, Hanse et al., 2016).

When comparing the challenges between the application of ErgoVSM and VSM, it is evident that the current state of the process stage takes more time when applying ErgoVSM compared to traditional VSM (Jarebrant, Winkel et al., 2016), since ergonomic data gathering requires more time and analysis. Despite this, the value of these data for decision-making by the management justifies the extra time (Sakthi et al., 2019).

\section{Discussion}

ErgoVSM originates from the need to have tools that increase ergonomic conscience and consider both Ergonomics and productivity in process planning (Mathiassen et al., 2004). ErgoVSM studies are regarded as a novel because the publications found were from 2004 to 2019, and the number of publications was reduced compared to Lean Manufacturing and environmental (Lean-Green) studies, which have become popular in recent years (Farias, Santos, Gohr., Oliveira \& Amorim, 2019; Siegel, Antony, Garza-Reyes, Cherrafi \& Lameijer, 2019; Zhan et al., 2018).

Even though Lean Manufacturing was born in the industrial sector (Fercoq, Lamouri \& Carbone, 2016), the application of ErgoVSM has happened mainly in the healthcare sectors of Nordic countries. It is related to the push that the NOVO Network has given to creating sustainable healthcare systems in the region (NOVO, 2020). Sustainable is defined as achieving efficiency in medical care, improving the work environment, and complying with patient care standards (Sinervo et al., 2013).

In countries such as Mexico, India, and Indonesia, which are considered countries with emerging economies (Wu, Chen, Chen \& Jeon, 2020), ErgoVSM applications focused on the manufacturing industry, which coincides with the characteristics of this type of economies that seeks economic growth by focusing on industrialization (Onyiriuba, 2016). On the other hand, economies regarded as developed, such as Sweden and Denmark (Li \& Lin, 2019), focused on improving the conditions of the healthcare sector, which coincides with the peculiarities of developed countries that focus on improving the quality of life of their inhabitants (Onyiriuba, 2016).

In the healthcare sector, ErgoVSM applications have focused mainly on considering both the physical and psychosocial factors by applying instruments developed by the authors themselves, while the industrial sector has 
focused on analyzing the physical factors using tools that are already known in the industry. Since it has been identified that the negative effects of the application of Lean Manufacturing can appear in both physical and mental factors (Koukoulaki, 2014; Pereiro da Silva, Tortorella \& Goncalves-Amaral, 2016; Westgaard \& Winkel, 2011), it is considered necessary to include instruments that help ergonomic, physical, and psychosocial analysis.

It was identified that ErgoVSM requires more build time than VSM due to the amount of extra data needed (Sakthi et al., 2019). Rother \& Shook (Rother \& Shook, 2009) estimate that building the current and future VSM for a family of products should conclude after two days of work, to then start to execute the improvement plan. Jarebrant, Winkel et al. (2016) compared ErgoVSM against VSM regarding the time required to build them, demonstrating that VSM took 18 hours of work against 24 hours required by ErgoVSM for the same production process. Even though ErgoVSM required more time, Sakthi et al. (2019) proved that the results of the methodology justify the additional time invested. Jarebrant, Winkel et al. (2016) concluded that the extra hours invested in ErgoVSM are reasonable because they yield positive results by improving the ergonomic conditions of the workers without negatively affecting productivity.

The inclusion of a greater amount of Lean Manufacturing tools in ErgoVSM happened mainly in industrial sector applications, while the healthcare sector focused on developing and improving ErgoVSM. Among the main Lean Manufacturing tools that were not used are 5S, which is considered key in implementing Lean Manufacturing and work environment improvement for being a tool that focuses on order, cleanliness, and discipline (Villaseñor \& Galindo, 2007). Bhattacharya et al. (Bhattacharya, Nand \& Castka, 2019) indicate that the application of 5S can improve the security and hygiene conditions of the workers.

\section{Conclusion}

The ErgoVSM methodology has been demonstrated to be an essential technique to improve the productive and ergonomic conditions of the processes, allowing to identify the areas of opportunity in industrial or healthcare processes. The extra time required for the construction of an ErgoVSM should be considered as an investment that will allow to improve the processes in an integral way.

Most of the studies analyzed to consider the physical and psychosocial factors of the workers. An area of opportunity that was identified to strengthen ErgoVSM was including factors relating to the physical environment of the workers, such as noise, temperature, and lightning, which affect not only the health of the workers but also their performance in the workplace. Including physical environmental conditions in the methodology will allow us to better to identify integral improvements in process and activity design.

The application of the ErgoVSM in different economic sectors will help in the inclusion of a greater number of ergonomic instruments, depending on the nature of the activities carried out by the employee, which allow us to make comparisons and evaluations of the results obtained. Having more case studies can encourage those responsible for designing and improving processes in the workplace to apply an ErgoVSM for decision-making. It is suggested the application in those activities recognized for the ergonomic risk for employees either due to the characteristics of their physical environment, the activities carried out by the employee or their identified psychosocial demands should be a priority.

\section{Acknowledgements}

The authors are grateful to the Universidad Autónoma de Baja California for facilitating access and use of their facilities and equipment to carry out this research.

\section{Declaration of Conflicting Interests}

The authors declared no potential conflicts of interest with respect to the research, authorship, and/or publication of this article.

\section{Funding}

The authors received no financial support for the research, authorship, and/or publication of this article. 


\section{References}

Abreu, M.F., Alves, A.C., \& Moreira, F. (2017). Lean-Green models for eco-efficient and sustainable production. Energy, 137, 846-853. https://doi.org/10.1016/j.energy.2017.04.016

Abu, F., Gholami, H., Mat-Saman, M.Z., Zakuan, N., \& Streimikiene, D. (2019). The implementation of lean manufacturing in the furniture industry: A review and analysis on the motives, barriers, challenges, and the applications. Journal of Cleaner Production, 234, 660-680. https://doi.org/10.1016/j.jclepro.2019.06.279

André, B., Heldal, F., \& Edwards, K. (2015). Abstract book - 9th NOVO Symposium, Quality in bealth care. Department of Health and Social science Sor-Trondelag University College. General.

Aqlan, F., Lam, S.S., Testani, M., \& Ramakrishnan, S. (2013). Ergonomic Risk Reduction to Enhance Lean Transformation. Proceedings of the 2013 Industrial and Systems Engineering Research Conference, November.

Arce, A., Romero-Dessens, L., \& Leon-Duarte, J. (2018). Ergonomic Value Stream Mapping: A Novel Approach to Reduce Subjective Mental Workload. Advances in Intelligent Systems and Computing, 792, 307-317.

https://doi.org/10.1007/978-3-319-60828-0

Bhattacharya, A., Nand, A., \& Castka, P. (2019). Lean-green integration and its impact on sustainability performance: A critical review. Journal of Cleaner Production, 236, 117697.

https://doi.org/10.1016/j.jclepro.2019.117697

Botti, L., Mora, C., \& Regattieri, A. (2017). Integrating ergonomics and lean manufacturing principles in a hybrid assembly line. Computers and Industrial Engineering, 111, 481-491. https://doi.org/10.1016/j.cie.2017.05.011

Boulila, A., Ayadi, M., \& Mrabet, K. (2018). Ergonomics study and analysis of workstations in Tunisian mechanical manufacturing. Human Factors and Ergonomics In Manufacturing, 28(4), 166-185. https://doi.org/10.1002/hfm.20732

Cuatrecasas, L. (2010). Gestión Integral de la Calidad. Profit Editorial Inmobiliaria.

Dombrowski, U., Reimer, A., \& Stefanak, T. (2019). Evaluation and Systematic Analysis of Ergonomic and Work Safety Methods and Tools for the Implementation in Lean Production Systems. In Advances in Human Factors and Systems Interaction (781, 332-342). Cham: Springer. https://doi.org/10.1007/978-3-319-94334-3

Dombrowski, U., Reimer, A., \& Wullbrandt, J. (2018). An Approach for the Integration of Non-ergonomic Work Design as a New Type of Waste in Lean Production Systems. Advances in Intelligent Systems and Computing, 592, 9-19. https://doi.org/10.1007/978-3-319-60366-7_2

Edwards, K. (2017). Integrating Work Environment Considerations Into Lean and Value Stream Mapping. 12th International Conference on Occupational Stress and Health. https://doi.org/10.1037/e506552017-001

Edwards, K. (2014). Ergonomic value stream mapping - can Lean and ergonomics go hand in hand? Human Factors in Organizational Desing and Management - XI Nordic Ergonomics Society Annuel Conference (123-126).

Edwards, K., Dudas, K., Hanse, J.J., Harlin, U., Hegstad, A., Holte, K.A. et al. (2009). Evaluation and development of an ergonomic complement to the Value Stream Mapping tool - a NOVO multicenter Study plan. In Winkel, J. (Ed.), 3rd NOVO R\&D Symposium - Sustainable Nordic bealth care systems (43).

Edwards, K., \& Winkel, J. (2013). Ergonomic Value stream Mapping (ErgoVSM) - potential for integrating work environment issues in a Lean rationalization process at a Danish hospital. 7 Th NOVO Symposium: A Nordic Model for Sustainable Systems in the Health Care Sector. http://orbit.dtu.dk/files/101179080/NOVO2014.pdf

Edwards, K., \& Winkel, J. (2016a). Accounting for effect modifiers in ergonomic intervention research. NES2016 - Ergonomics in Theory and Practice. 48th Annual Conference of Nordic Ergonomics and Human Factors Society (1, 191-195).

Edwards, K., \& Winkel, J. (2016b). Some key issues in the development of ergonomic intervention tools. NES2016 - Ergonomics in Theory and Practice. 48th Annual Conference of Nordic Ergonomics and Human Factors Society (176-178). 
Edwards, K., Winkel, J., Laine, M., Sinervo, T., Sjovold, E., Bragadottir, H. et al. (2012). Abstract book - 6th NOVO Symposium. Department of Health- and Social science Sor-Trondelag University College.

Enez, K., \& Nalbantoğlu, S.S. (2019). Comparison of ergonomic risk assessment outputs from OWAS and REBA in forestry timber harvesting. International Journal of Industrial Ergonomics, 70(January), 51-57.

https://doi.org/10.1016/j.ergon.2019.01.009

Farias, L.M.S., Santos, L.C., Gohr, C.F., Oliveira, L.C., \& Amorim, M.H.S. (2019). Criteria and practices for lean and green performance assessment: Systematic review and conceptual framework. Journal of Cleaner Production, 218, 746-762. https://doi.org/10.1016/j.jclepro.2019.02.042

Faulkner, W., \& Badurdeen, F. (2014). Sustainable Value Stream Mapping (Sus-VSM): Methodology to visualize and assess manufacturing sustainability performance. Journal of Cleaner Production, 85, 8-18.

https://doi.org/10.1016/j.jclepro.2014.05.042

Fercoq, A., Lamouri, S., \& Carbone, V. (2016). Lean/Green integration focused on waste reduction techniques. Journal of Cleaner Production, 137, 567-578. https://doi.org/10.1016/j.jclepro.2016.07.107

Fernandes, A., Figueiredo, M., Ribeiro, J., Neves, J., \& Vicente, H. (2020). Psychosocial Risks Assessment in Cryopreservation Laboratories. Safety and Health at Work. https://doi.org/10.1016/j.shaw.2020.07.003

Flumerfelt, S., \& Wenson, J. (2019). Accelerating sustainability with lean leadership. In Alves, A.C., Flumerfelt, S., Kahlen, FJ., \& Siriban-Manalang, A.B. (Eds.), Lean Engineering for Global Development (1, 385-403). Springer Nature. https://doi.org/10.1007/978-3-030-13515-7_13

Gunnarsdóttir, S., \& Birgisdóttir, B.D. (2013). Ergonomic Value stream Mapping (ErgoVSM) - potential for integrating work environment issues in a Lean rationalization process at University Hospital on Iceland. 7th NOVO Symposium: A Nordic Model for Sustainable Systems in the Health Care Sector. http://orbit.dtu.dk/files/101179080/NOVO2014.pdf

Gutiérrez, H., \& de la Vara, R. (2013). Control estadístidco de la calidad y Seis Sigma (3th ed.). Mc Graw Hill.

Hasle, P., Starheim, L., Jensen, P.L., \& Diekmann, B. J. (2016). Value stream mapping as a tool for systematic employee based improvement of the psychosocial work environment in hospitals. 23rd EUROMA Conference Interactions (1-6). https://doi.org/10.5465/ambpp.2016.14196abstract

Hasle, P., Starheim, L., Jensen, P.L., Diekmann, B.J., \& Jensen, N.B. (2016). Lean as a Tool for Systematic Employee Based Improvement of Psychosocial Factors in Hospitals. Academy of Management Proceedings, 1, 14196. https://doi.org/10.5465/ambpp.2016.14196abstract

Hernandez-Matias, J.C., \& Vizan-Idoipe, A. (2013). Lean manufacturing. Conceptos, técnicas e implantación. In Human Systems Management. Fundacion EOI. https://doi.org/10.3233/HSM-1993-12106

IEA (2019). Definition and Domains of Ergonomics - IE A Website. https://www.iea.cc/whats/index.html

Imai, M. (2001). Kaizen. La clave de la ventaja competitiva japonesa (13th ed.). Grupo Patria Cultural.

Imai, M. (2012). Gemba Kaizen (2nd ed.). Mc Graw Hill.

Jarebrant, C., Birgisdóttir, B.D., Dudas, K., Edwards, K., Gunnarsdóttir, S., Harlin, U. et al. (2014). Development of a tool for integrating Value Stream Mapping and ergonomics in healthcare - A Nordic Multicenter study. The 7 th Nordic Working Life Conference (1, 1689-1699).

Jarebrant, C., Dudas, K., Harlin, U., Hanse, J.J., \& Winkel, J. (2009). A tool for considering job content in the development of production flow by value stream mapping at hospitals. In Winkel, J. (Ed.), 3rd NOVO R\&D Symposium - Sustainable Nordic bealth care systems (42).

Jarebrant, C., Dudas, K., Harlin, U., Hanse, J.J., \& Winkel, J. (2010). A tool for development of sustainable healt care systems by integrating considerations for performance and job content. Seventh International Scientific Conference on Prevention of Work-Related Musculoskeletal Disorders, PREMUS 2010 (141). 
Jarebrant, C., Hanse, J.J., Harlin, U., Ulin, K., Winkel, J., Edwards, K. et al. (2016). Ergonomic Value Stream Mapping. Tool and User Guide.

Jarebrant, C., Winkel, J., Hanse, J.J., Mathiassen, S.E., \& Birgitta, O. (2016). ErgoVSM: A Tool for Integrating Value Stream Mapping and Ergonomics in Manufacturing. Human Factors and Ergonomics in Manufacturing \& Service Industries, 26(2), 191-204. https://doi.org/10.1002/hfm.20622

Khani, R., Salehi, A., \& Sajad, S. (2018). Relationship Between Lean Manufacturing and Ergonomics. Advances in Intelligent Systems and Computing, 606(October), 1-5. https://doi.org/10.1007/978-3-319-60474-9

Kim, I.J. (2016). Cognitive Ergonomics and Its Role for Industry Safety Enhancements. Journal of Ergonomics, 6(4), 1-4. https://doi.org/10.4172/2165-7556.1000e158

Kim, I.J. (2017). The Function of Ergonomics in Lean Manufacturing Design and Control. Journal of Ergonomics, 07(05), 5-7. https://doi.org/10.4172/2165-7556.1000e172

Koukoulaki, T. (2014). The impact of lean production on musculoskeletal and psychosocial risks: An examination of sociotechnical trends over 20 years. Applied Ergonomics, 45(2 Part A), 198-212.

https://doi.org/10.1016/j.apergo.2013.07.018

Leong, W.D., Lam, H.L., Ng, W.P.Q., Lim, C.H., Tan, C.P., \& Ponnambalam, S.G. (2019). Lean and Green Manufacturing-a Review on its Applications and Impacts. Process Integration and Optimization for Sustainability, 3(1), 5-23. https://doi.org/10.1007/s41660-019-00082-x

Li, J., \& Lin, B. (2019). The sustainability of remarkable growth in emerging economies. Resources, Conservation and Recycling, 145(January), 349-358. https://doi.org/10.1016/j.resconrec.2019.01.036

López-Acosta, M., García-Vilches, S., Velarde-Cantú, J.M., \& Chacara-Montes, A. (2019). Implementation of the lean ergonomics approach to process performance improvement. Journal of Microfinance Planning and Control, 5(15), 10-21. https://doi.org/10.35429/JMPC.2019.15.5.10.21

Madariaga-Neto, F. (2018). Lean manufacturing: Exposición adaptada a la fabricación repetitiva de familias de productos mediante procesos discretos (2nd ed.). Bubok Publishing.

Mathiassen, S.E., Jarebrant, C., Birgitta, O., \& Winkel, J. (2004). Ergonomic Value Stream Mapping - an integrated rationalization tool considering ergonomics and productivity. Fifth International Scientific Conference on Prevention of Workerelated Musculoskeletal Disorders (77-78). https://doi.org/10.1007/s10195-007-0090-z

Neumann, W.P., \& Winkel, J. (2005). Organisational Design and the Integration of Human Factors in Production System Development. 10th International Conference on Human Aspects of Advance Manufacturing: Agility and Hybrid Automation (10). https://doi.org/10.1016/j.apergo.2008.09.010

NOVO (2020). About NOVO. https://www.novo-network.dk/about novo

Obregón-Sánchez, M. (2016). Fundamentos de Ergonomía (1st ed.). Grupo Editorial Patria.

Onyiriuba, L. (2016). Questions in the Making of Emerging Economies and Markets. Emerging Market Bank Lending and Credit Risk Control (5-24). https://doi.org/10.1016/b978-0-12-803438-5.00001-5

Otto, A., \& Battaïa, O. (2017). Reducing physical ergonomic risks at assembly lines by line balancing and job rotation: A survey. Computers and Industrial Engineering, 111, 467-480. https://doi.org/10.1016/j.cie.2017.04.011

Pampanelli, A.B., Found, P., \& Bernardes, A.M. (2014). A Lean \& Green Model for a production cell. Journal of Cleaner Production, 85, 19-30. https://doi.org/10.1016/j.jclepro.2013.06.014

Pereiro da Silva, M., \& Goncalves-Amaral, F. (2019). ErgoVSM on a hospital pharmaceutical stream. In Occupational and Environmental Safety and Health. Studies in Systems, Decision and Control (202, 439-445). Springer Nature. https://doi.org/10.1007/978-3-030-14730-3_47

Pereiro da Silva, M., Tortorella, G.L., \& Goncalves-Amaral, F. (2016). Psychophysical Demands and Perceived Workload - An Ergonomics Standpoint for Lean Production in Assembly Cells. Human Factors and Ergonomics in Manufacturing, 26(6), 643-654. https://doi.org/10.1002/hfm.20404 
Radnor, Z.J., Holweg, M., \& Waring, J. (2012). Lean in healthcare: The unfilled promise? Social Science and Medicine, 74(3), 364-371. https://doi.org/10.1016/j.socscimed.2011.02.011

Rother, M., \& Shook, J. (2009). Learning to See. Value-Stream Mapping to Create Value and Eliminate Muda. Lean Enterprise Institute.

Sakthi, N.T., Jeyapaul, R., Vimal, K.E.K., \& Mathiyazhagan, K. (2019). Integration of human factors and ergonomics into lean implementation: ergonomic-value stream map approach in the textile industry. Production Planning and Control, 0(0), 1-18. https://doi.org/10.1080/09537287.2019.1612109

Santos, Z.G., Vieira, L., \& Balbinotti, G. (2015). Lean Manufacturing and Ergonomic Working Conditions in the Automotive Industry. Procedia Manufacturing, 3(Ahfe), 5947-5954. https://doi.org/10.1016/j.promfg:2015.07.687

Siegel, R., Antony, J., Garza-Reyes, J.A., Cherrafi, A., \& Lameijer, B. (2019). Integrated green lean approach and sustainability for SMEs: From literature review to a conceptual framework. Journal of Cleaner Production, 240, 118205. https://doi.org/10.1016/j.jclepro.2019.118205

Sinervo, T., Laine, M., \& Pekkarinen, L. (2013). 7th NOVO Symposium: A Nordic Model for Sustainable Systems in the Health Care Sector.

Spagnol, G.S., Min, L.L., \& Newbold, D. (2013). Lean principles in healthcare: An overview of challenges and improvements. In IFAC Proceedings Volumes (IFAC-PapersOnline) (6, part 1). IFAC. https://doi.org/10.3182/201309113-BR-3021.00035

Suryoputro, M.R., Sari, A.D., Burhanudin, R., \& Sugarindra, M. (2017). Lean production design using value stream mapping and ergonomics approach for waste elimination on buffing panel upright process. IOP Conference Series: Materials Science and Engineering, 277(1), 0-7. https://doi.org/10.1088/1757-899X/277/1/012015

Thatcher, A., \& Yeow, P.H.P. (2018). Ergonomics and Human Factors for a Sustainable Future: Current Research and Future Possibilities. Springer Nature. https://doi.org/10.1007/978-981-10-8072-2

The Nordic Council and the Nordic Council of Ministers (2018). Front page - Nordic cooperation. https://www.norden.org/en

Villaseñor, A., \& Galindo, E. (2007). Manual de Lean Manufacturing (1st ed.). Editorial Limusa.

Wahab, A.N.A., Mukhtar, M., \& Sulaiman, R. (2013). A Conceptual Model of Lean Manufacturing Dimensions. Procedia Technology, 11(Iceei), 1292-1298. https://doi.org/10.1016/j.protcy.2013.12.327

Westgaard, R.H., \& Winkel, J. (2011). Occupational musculoskeletal and mental health: Significance of rationalization and opportunities to create sustainable production systems - A systematic review. Applied Ergonomics, 42(2), 261-296. https://doi.org/10.1016/j.apergo.2010.07.002

Winkel, J. (2009). 3rd NOVO R\&D Symposium - Sustainable Nordic health care systems.

Winkel, J., Birgisdóttir, B.D., Dudas, K., Edwards, K., Gunnarsdóttir, S., Harlin, U. et al. (2012). A Nordic work environment complement to Value Stream Mapping for sustainable patient flows at hospitals - A NOVO Multicenter study. 6th NOVO Symposium (58-59).

Winkel, J., Dudas, K., Harlin, U., Jarebrant, C., \& Hanse, J.J. (2013). Ergonomic Value stream Mapping (ErgoVSM) - potential for integrating work environment issues in a Lean rationalization process at two Swedish Hospitals. 7th NOVO Symposium: A Nordic Model for Sustainable Systems in the Health Care Sector. http://orbit.dtu.dk/files/101179080/NOVO2014.pdf\%0Ahttps://research.chalmers.se/publication/190745

Winkel, J., Edwards, K., Birgisdóttir, B.D., \& Gunnarsdóttir, S. (2015). Facilitating and inhibiting factors in change processes based on the lean tool "value stream mapping": an exploratory case study at hospital wards. International Journal of Human Factors and Ergonomics, 3(3/4), 291. https://doi.org/10.1504/ijhfe.2015.073000

Winkel, J., Edwards, K., Birgisdóttir, B.D., Jarebrant, C., Hanse, J.J., Gunnarsdóttir, S. et al. (2015). A Nordic evaluation of a work environment complement to Value Stream Mapping for increased sustainability of patient flows at hospitals - The NOVO Multicentre Study I. 9th NOVO Symposium, Quality in Health Care. 
Womack, J.P., Jones, D.T., \& Roos, D. (1990). The machine that changed the world. New York: Rawson Associates.

Wu, J., Chen, L., Chen, M., \& Jeon, B.N. (2020). Diversification, efficiency and risk of banks: Evidence from emerging economies. Emerging Markets Review, 100720. https://doi.org/10.1016/j.ememar.2020.100720

Zhan, Y., Tan, K.H., Ji, G., Chung, L., \& Chiu, A.S.F. (2018). Green and lean sustainable development path in China: Guanxi, practices and performance. Resources, Conservation and Recycling, 128, 240-249.

https://doi.org/10.1016/j.resconrec.2016.02.006

Journal of Industrial Engineering and Management, 2021 (www.jiem.org)

\section{(c) (1) $(9$}

Article's contents are provided on an Attribution-Non Commercial 4.0 Creative commons International License. Readers are allowed to copy, distribute and communicate article's contents, provided the author's and Journal of Industrial Engineering and Management's names are included. It must not be used for commercial purposes. To see the complete license contents, please visit https://creativecommons.org/licenses/by-nc/4.0/. 